\title{
ENTEROBACTERIACEAE IN MOUTH AND CLOACA OF PODOCNEMIS EXPANSA AND P. UNIFILIS (TESTUdiNES: CHELONIA) POPULATIONS OF NATIONAL PARK OF ARAGUAIA PLAINS, BRAZIL
}

\section{Paula Benevides de Morais*; Denise Rodrigues de Souza; Francisca Maria Pinheiro de Sousa; Kleverson Wessel de Oliveira, Raphael Sanzio Pimenta}

Laboratório de Microbiologia Ambiental e Biotecnologia, Universidade Federal de Tocantins, Palmas, TO, Brasil.

Submitted: March 07, 2010; Returned to authors for corrections: April 21, 2010; Approved: January $13,2011$.

\begin{abstract}
Shigella flexnerii and Escherichia coli were the most frequent Gram-negative bacteria found in the mouth cavity and cloacae of the turtles Podocnemis expansa and P. unifilis on beaches in the National Park of Araguaia, Brazil. Reptiles are known as Salmonella carriers, despite rarely isolated in these turtles.
\end{abstract}

Key words: Salmonella; Shigella; Enterobacteriaceae; Turtles; Bananal Island

The association of reptiles with human pathogens, especially Salmonella, has been largely documented $(3,8)$. Mermin et al. (11) suggest that reptile and amphibian exposure is associated with $\approx 74,000$ Salmonella yearly infections in the United States. Turtles have been involved as vectors of salmonellae in captivity as well as in the wild $(8,16)$. Moreover, other human enteric pathogens have also been isolated in turtles $(18,19)$.

Studies regarding the microbiota of Brazilian reptiles in the wild are rare, but Serafini et al. (21) showed that the Pantanal alligator (Caiman crocodilus yacare) and the "jacarétinga" (Caiman crocodilus crocodilus) carry Aeromonas sp., Acinetobacter spp., Citrobacter freundii, Escherichia coli and Pseudomonas sp. Abalem de Sá and Solari (1) found Salmonella spp. in $39.1 \%$ of Brazilian and imported pet reptiles, including chelonians. Ferronato et al. (7) isolated E. coli, Klebsiella pneumoniae, Enterobacter aglomerans, $C$. freundii and Bacillus sp. in oral samples of Phrynops geoffroanus turtles.

Our work aims at detecting Enterobacteriaceae in the mouth cavity and the cloacae of nesting $P$. expansa and $P$. unifilis, which are extensively used as food as well as for manufacturing utilitarian handicrafts by local populations dwelling along the Amazon and Araguaia/Javaés river basins (17). This causes pressure toward extinction, and also raises the issue concerning health risk to those human populations in contact with these reptiles.

This study is located within the National Park region of the Araguaia Plains (Fig. 1). Field collections were carried out in August and November 2005 under research license 081/04 IBAMA/RAN. Eighteen female specimens of $P$. expansa were caught on the beaches during oviposition, and 30 males and females of $P$. unifilis captured in the river water while feeding and submitted to cloacal and mouth cavity swabbing.

*Corresponding Author. Mailing address: Laboratório de Microbiologia Ambiental e Biotecnologia, Campus Universitário de Palmas - UFT, ALCNO 14, NS 15, Bl. II, sl. 05. Palmas - Tocantins, Brazil. CEP77020220.; Tel/Fax: +55 63 32328007.; E-mail: moraispb@uft.edu.br 
This research project has been approved by the Research Ethics Committee of the Federal University of Tocantins (Universidade Federal do Tocantins). The swabs were incubated in tubes containing Muller-Kauffmann tetrationate broth (Merck KGaA, Darmstadt, Germany) for one to four days at $35-37^{\circ} \mathrm{C}$ and taken to the laboratory where they were inoculated on Petri dishes containing EMB Agar (Merck KGaA, Darmstadt, Germany), McConckey Agar (Merck KGaA, Darmstadt, Germany) and SS Agar (Merck KGaA, Darmstadt, Germany) and then incubated for $24 \mathrm{~h}$ at $37^{\circ} \mathrm{C}$. Typical colonies were purified and identified by Gram staining,
TSI (Merck KGaA, Darmstadt, Germany) screening and API $20 \mathrm{E}^{\mathrm{TM}}$ (BioMerieux, Jacarepaguá, Rio de Janeiro, Brazil) kit tests. Only Gram-negative bacilli and cocobacilli were identified by API20E. APIWEB ${ }^{\mathrm{TM}}$ (BioMerieux, Jacarepaguá, Rio de Janeiro, Brazil) was used for identification. Results are expressed as the frequency of occurrence of each bacterial species found within each sampled individual, and two or more isolates from a single individual sample were considered as a single isolate. Salmonella serotyping was kindly carried out by LACEN-TO lab, according to standard procedures for human isolates.

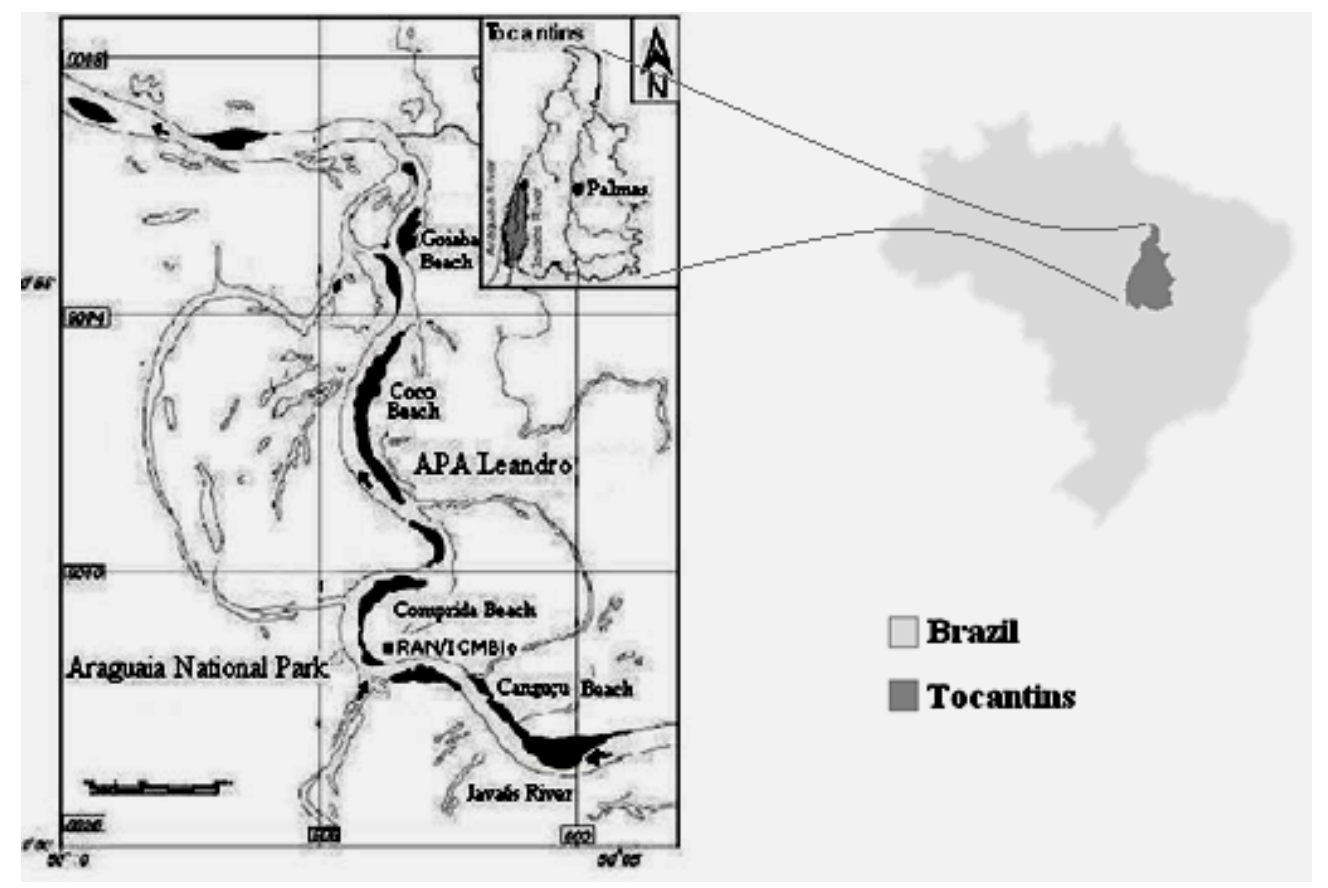

Figure 1. Location map of the study area at the National Park of Araguaia Plains with the nesting beaches of Canguçu, Comprida, Coco and Goiaba and the Javaés River. At the upper right side, the location of the National Park of Araguaia Plains in the Tocantins State, that is shown in the map of Brazil, at the right.

Thirteen species of Gram-negative bacteria were isolated from P. expansa and P. unifilis. Chromobacterium violaceum and $P$. aeruginosa along with two species of Citrobacter and one species of Salmonella were the most frequent bacteria from the mouth samples of 18 nesting $P$. expansa (Table 1). Five of the samples were negative for growth of enterobacteria and eight isolates could not be identified by the employed methods. Acinetobacter calcoaceticus and $C$. violaceum were the most 
frequent species in the mouth of $P$ unifilis, and one Aeromonas and two Citrobacter species, E. coli, E. cloacae and Salmonella Choleraesuis subsp. arizonensis were isolated at low frequencies along with four unidentified ones. All samples were positive for the presence of enterobacteria. Shigella flexnerii and E. coli, which comprised 28 out of 32 isolates from cloacal samples of $P$. expansa. Cloacal samples of $P$. unifilis resulted in the isolation of $S$. flexnerii (nine isolates), $E$. coli (six isolates) and K. pneumoniae subsp. pneumoniae (six isolates) and one isolate each of $C$. youngae, $H$. alvei and $S$. ficaria. Seven isolates from cloacae of $P$. unifilis and four from $P$. expansa showed a similar and unknown profile (profile 1 in Table 1) in API20E $\mathrm{E}^{\mathrm{TM}}$.

Table 1. Frequency of occurrence of bacterial species in mouth cavity and cloacae of $P$. expansa and $P$. unifilis adults in four beaches of the Javaés River border of National Park of Araguaia.

\begin{tabular}{|c|c|c|c|c|}
\hline \multirow[t]{2}{*}{ Species } & \multicolumn{2}{|c|}{$\begin{array}{c}\text { P. expansa } \\
\left(\mathrm{n}^{\mathrm{a}}=18\right)\end{array}$} & \multicolumn{2}{|c|}{$\begin{array}{l}\text { P. unifilis } \\
(\mathrm{n}=30)\end{array}$} \\
\hline & Mouth & Cloaca & Mouth & Cloaca \\
\hline Aeromonas salmonicida subsp. salmonicida & & & 1 & \\
\hline Acinetobacter calcoaceticus & & & 4 & \\
\hline Chromobacterium violaceum & 4 & & 4 & \\
\hline Citrobacter freundii & 1 & & 1 & \\
\hline Citrobacter youngae & 1 & & 1 & 1 \\
\hline Escherichia coli & & 8 & 1 & 6 \\
\hline Enterobacter cloacae & & & 1 & \\
\hline Hafnia alvei & & & & 1 \\
\hline Klebsiella pneumoniae subsp. pneumoniae & & & & 6 \\
\hline Pseudomonas aeruginosa & 2 & & 2 & 1 \\
\hline Salmonella Cholerasuis subsp. arizonae & 1 & & 1 & \\
\hline Serratia ficaria & & & & 1 \\
\hline Shigella flexnerii & & 20 & & 9 \\
\hline Non-identified profile 1 & & 4 & & 7 \\
\hline Non-identified profile 2 to 3 & 8 & & & \\
\hline Non-identified profiles 4 to 8 & & & 12 & \\
\hline Total & 17 & 32 & 28 & 32 \\
\hline
\end{tabular}

The isolation of Shigella and Klebsiella associated with both turtle species may very well indicate health risk to humans consuming their meat. Shigella has rarely been reported as associated with turtles, however solely by Mahmoud et al. (10) who isolated Shigella spp. from the Chelonya midas oviductal fluid and by Dickinson et al. (6) from tortoises. David et al. (5) proposed that polluted water was the source of Shigella in the Nile tilapia in a Kenyan lake, but the Javaés river water presents as highly pristine, according to Morais et al. (13). Santoro et al. (18) verified that $K$. pneumoniae was the most common microbe identified and the Enterobacteriaceae family was the largest Gram-negative group of bacteria in 70 nesting green turtles (Chelonia mydas) from Tortuguero National Park, Costa Rica. Boede and Hernández (2) found Klebsiella spp. implicated in enteritis and dermatitis in the turtle Pseudemis scripta.

Similar to this study, E. coli was prevalent in the cloaca and feces of the estuarine diamondback terrapin (Malaclemys terrapin) (9) and Phrynops geoffroanus (7). Oros et al. (14) associated E. coli with lesions in Caretta caretta, and Raidal et al. (15) to juvenile mortality of Chelonia midas. Santoro et al. (19) found Aeromonas spp. and C. freundii but not S. flexnerii, 
E. coli or $C$. violaceum as frequent bacteria in Lepidochelys olivacea, a chelonian from Costa Rica.

Salmonella was not obtained from cloaca of the chelonians and only two isolates were obtained from mouth samples. Salmonella Choleraesuis subsp. arizonae was also isolated from $P$. unifilis eggs in the same area (13). It might be possible that the failure to detect Salmonella in cloacal samples was due to a methodological bias. Harwood et al. (9) argues that the method of cloacal swabs for sampling presents a great deal of variability due to individual recent activities. In this study, recent oviposition by an individual turtle was not unlikely since the majority of $P$. expansa individuals were females captured on nesting beaches. Also, wild turtles are believed to shed Salmonella at lower rates than captive turtles because they either lack exposure to stressors that increase shedding rates or because they are not natural carriers of the bacterium (16).

We conclude that Enterobacteriaceae are part of the normal microbiota of mouth and cloacae of Podocnemis expansa and $P$. unifilis in the pristine area of Araguaia National Park and surrounding Plains, since sand and water are not contaminated as shown by Morais et al. (13). In regard to the fact that the cold-blooded turtles shed coliform bacteria, including $E$. coli, in their cloacae may have public health significance.

\section{ACKNOWLEDGEMENTS}

This work was sponsored by Conselho Nacional de Desenvolvimento Científico e Tecnológico (CNPq) through grant \#620009/2004-7. We would like to thank Dr. Adriana Malvasio and her team for help in the field work.

\section{REFERENCES}

1. Abalem de Sá, I.V.; Solari, C. (2001). Salmonella in Brazilian and imported pet reptiles. Braz. J. Microbiol. 32(4), 293-297.

2. Boede, E.O.; Hernández, O. (2004). Enfermidades em tortugas arrau o del Orinoco, Podocnemis expansa, mantenidas em zoocriaderos venezoelanos. Rev. Cient. FCV-LUZ. 14, 395-403.

3. Briones, V.; Tellez, S.; Goyache, J.; Ballesteros, C.; del Pilar Lanzarot, M.; Lanzarot, M.D.; Dominguez, L.; Fernandez-Garayzabal, J.F. (2004). Salmonella diversity associated with wild reptiles and amphibians in Spain. Environ. Microbiol. 6, 868-871.

4. Craven, K.S.; Awong-Taylor, J.; Griffiths, L.; Bass, C.; Muscarella, M. (2007). Identification of bacterial isolates from unhatched Loggerhead (Caretta caretta) sea turtle eggs in Georgia, USA. Marine Turtle Newslet. 115, 9-11.

5. David, O. M.; Wandili, B.; Kakai, R.; Waindi, E. N. (2009). Isolation of Salmonella and Shigella from fish harvested from the west gulf of Lake Victoria, Kenya. JIDC 3, 99-104.

6. Dickinson, V.M.; Duck, T.M.; Schwalbe, C.R.; Jarchow, J.L.; Trueblood, M.H. (2001). Nasal and cloacal bacteria in free-ranging desert tortoises from the Western united States. J. Wildlife Dis. 37, 252257.

7. Ferronato, B.O; Marques, T.S.; Souza, F.L.; Verdade, L.M.; Matushima, E.R. (2009). Oral bacterial microbiota and traumatic injuries of freeranging Phrynops geoffranus (Testudines, Chelidae) in southeastern Brazil. Phyllomedusa. 8(11), 19-25.

8. Gaertner, J.P.; Hahn, D.; Jackson, J.; Forstner, M.R.J.; Rose, F.L. (2008). Detection of Salmonellae in captive and free-ranging turtles using enrichment culture and polymerase chain reaction. J. Herpetol. 42, 223231.

9. Harwood, V. J.; Butler, J.; Parrish, D.; Wagner, V. (1999). Isolation of fecal coliform bacteria from the diamondback terrapin (Malaclemys terrapin centrata) Appl.Environ. Microbiol., 65, 865-867.

10. Mahmoud, I. Y.; Al-Zadjali, M.; Al-Bahry, S. N.; Elshafie, A.; AlKindi, A. Y.; Al-Alawi, W.; Al-Harthy, A.; Khan, T. (2008) Multiple antibiotic resistant gram negative bacteria from the oviductal fluid of the green turtles (Chelonia mydas) during egg laying. NOAA Technical Memorandum NMFS SEFSC [NOAA Tech. Mem. NMFS SEFSC] 569, 22.

11. Mermin, J.; Hutwagner, L.; Vugia, D.; Shallow, S.; Daily, P.; Bender, J.; Koehler, J.; Marcus, R.; Ângulo, F.J. (2004). Reptiles, amphibians, and human Salmonella infection: A population-based, case-control study. Clin. Infec. Dis. 38, S253-S261.

12. Mo, C.L.; Salas, I.; Caballero, M. (1990). Are fungi and bacteria responsible for olive ridley's egg loss? In Richardson, T.H., Richardson, J.I. (Eds). Proceedings of the 10th annual workshop in sea turtle biology and conservation. NOAA technical memorandum NMFS-SEFC. 278, 249-251.

13. Morais, P. B.; Oliveira, K. W.; Malvásio, A.; Ataíde, A. G.; Pimenta, 
R.S. (2010). Bacterial microbiota in eggs of Podocnemis expansa and Podocnemis unifilis (Testudines: Chelonia) in pristine are of National Park of Araguaia Plains, Brazil. J. Zoo Wildlife Med., accepted for publication.

14. Oros, J.; Torrent, A.; Calabuig, P.; Déniz, S. (2005) Diseases and causes of mortality among sea turtles stranded in the Canary Islands, Spain (1998-2001). Dis. Aquat. Org. 63, 13-24.

15. Raidal, S.R.; Ohara, M.; Hobbs, R.P.; Prince, R. (1998). Gram-negative bacterial infections and cardiovascular parasitism in green sea turtles (Chelonia mydas). Aust. Vet. J. 76, 415-417.

16. Saelinger, C.A.; Lewbart, G.A.; Christian, L.S.; Lemons, C.L. (2006). Prevalence of Salmonella spp. in cloacal, fecal, and gastrointestinal mucosal samples from wild North American turtles. J. Am. Vet. Med. Assoc. 229, 266-268.

17. Salera Jr, G.; Malvasio, A.; Portelinha, T.C.G. (2009). Avaliação da predação de Podocnemis expansa e Podocnemis unifilis (Testudines, Podocnemididae) no rio Javaés, Tocantins. Acta Amaz. 39, 197-204.
18. Santoro, M.S.; Hernández, G.; Caballero, M.S.; García, F. (2006a). Aerobic bacterial flora of nesting green turtles (Chelonia mydas) from Tortuguero National Park, Costa Rica. J. Zoo. Wildlife Med. 37, 549-552.

19. Santoro, M.S.; Hernández, G.; Caballero, M.S.; García, F. (2008). Potential bacterial pathogens carried by nesting leatherback turtles (Dermochelys coriacea) in Costa Rica. Chel. Cons. Biol. 7, 104-108.

20. Santoro, M.S.; Orrego, C.M.; Gómez, G.H. (2006b). Flora bacteriana cloacal y nasal de Lepdochelys olivacea (Testudines: Chelonia) em el Pacifico norte de Costa Rica. Rev. Biol. Trop. 54, 43-48.

21. Serafini, P.P.; Guarrido, M.M.; Biesdorf, M S.; Vianna, V.O.; Klostermann, D.Z.; Oczkovski, F.I.; Machado, D. (2006). Microbiota oral e cloacal de jacaré- do-Pantanal (Caiman crocodilus yacare) e jacaré-tingá (C.c. crocodilus). XXVI Congresso Brasileiro de Zoologia, Londrina, PR.

22. Wyneken, J.; Burke, T.J.; Salmon, M.; Pedersen, D.K. (1988). Egg failure and relocated sea turtle nests. J. Herpetol. 22, 88-96. 